FRONTIERS OF CAPITAL 



\section{FRONTIERS OF CAPITAL}

ETHNOGRAPHIC REFLECTIONS ON THE NEW ECONOMY

Edited by MELISSA S. FISHER and GREG DOWNEY

Duke University Press Durham and London 2006 
(C) 2006 Duke University Press All rights reserved

Printed in the United States

of America on acid-free paper $\infty$

Designed by Amy Ruth Buchanan

Typeset in Minion by Keystone

Typesetting, Inc.

Library of Congress Cataloging-in-

Publication Data appear on the last printed page of this book. 